\title{
A Critique of Legal Protection of China's Outward Direct Investment in ASEAN - Implications of Guangdong Corporations
}

\author{
Jingjia Ke \\ School of Law, Guangdong University of Finance and Economics, Guangzhou, P.R.China \\ Email address: \\ kejingjia@gdufe.edu.cn \\ To cite this article: \\ Jingjia Ke. A Critique of Legal Protection of China's Outward Direct Investment in ASEAN - Implications of Guangdong Corporations. \\ International Journal of Law and Society. Vol. 2, No. 1, 2019, pp. 5-15. doi: 10.11648/j.ijls.20190201.12
}

Received: January 8, 2019; Accepted: February 22, 2019; Published: May 23, 2019

\begin{abstract}
As a result of the development of the "One Belt One Road" and the strategy of "Going Out" for multinational enterprises, China's outward direct investments have grown rapidly. During the transformation period from a capital-importing to a capital-exporting country, issues of legal barriers, investment risks and insufficient investment disputes mechanism on China's outward investment to Association of South East Asian Nations (ASEAN) have surfaced. Although ASEAN countries and China agreed on further liberalization in investment, the effects of investment agreements and Bilateral Investment Treaties on risk prevention and safeguarding investment interests have rarely been discussed and examined via empirical studies. In examine legal barriers, major investment risks, and investment dispute settlement mechanisms of China's multinational enterprises in ASEAN States, this study selects 30 state-owned enterprises and private companies among 300 Guangdong businesses, which largely invested in ASEAN via data analyses, surveys, and interviews. Nevertheless, the obstacles in investment treatment and high political risks as a result of outward investment in ASEAN suggest that China's multinational enterprise should start to seek multiple investment insurance either from Sinosure or the international financial institution, or advancing investment treaties and formulating a "Going-in " strategy. The findings of this research provide a reference to Chinese multinational enterprises for the investment protection and for the launching of investment litigation of these Chinese multinational enterprises whenever it is required.
\end{abstract}

Keywords: One Belt One Road, ASEAN, China’s Multinational Enterprises, Chinese Outward Investment, Investment Protection

\section{Introduction}

\subsection{Overview of China's Overseas Investment in ASEAN}

China's overseas investment has grown rapidly and steadily ever since the era of "One Belt One Road" (OBOR) initiative, which was first proposed by President Xi as part of the announcement of the Silk Road Economic Belt and the $21^{\text {st }}$ century Maritime Silk Road in September 2013. The Vision and Actions on Jointly Building the Silk Road Economic Belt and the $21^{\text {st }}$ Century Maritime Silk Road issued on $28^{\text {th }}$ of March 2015, further promoted connectivity and enhanced the investment facilitation between China and ASEAN countries along the Belt and Road in-depth regional cooperation of higher standards. [1] As of October 2018,
China has signed OBOR cooperation documentation with 130 countries and international organization of the world, which includes ASEAN States, United Kingdom, and called for strengthening the process of regional economic cooperation via UN Security Council Resolution 2344 (2017). [2]

In 2017, China's outward investment had reached 158.29 billion USD, $12.7 \%$ of which are investments from OBOR countries, and $8.9 \%$ of which (almost USD 14.12 billion) originates from ASEAN countries. [3] Despite the declining of total outward investment flows, China's investment to 10 ASEAN countries increased for $37.4 \%$. There were 7 ASEAN countries among top ten countries of outward investment flows in the countries along the route, which constitute by Singapore(1), Malaysia(3), Indonesia(4), 
Laos(6), Thailand(7), Vietnam(8), Cambodia(9). [4] The investments to Laos and Cambodia have arisen sharply comparing to the figure of last year, China's 4700 multinational enterprises (MNEs) established their offices in ASEAN countries with 35.3 thousands local employees and substantially invested in sectors of manufacturing (22.5\%), wholesale and retail trade $(17.3 \%)$, lease and business services (15.2\%), transportation, storage and postal services (5.4\%), financial services (5.2\%)and production and supply of electricity, heat, gas and water (4.5\%). [5] Among China's outward FDI flows alongside Belt and Road countries, Guangdong outward FDI (USD 11.77 billion) ranks the second largest in the whole nation. [6] Among Guangdong's FDI investments to the OBOR countries, $75.25 \%$ were flowed into the ASEAN states, after Indian which account for $19.87 \%$ of total investment along the OBOR countries. [7] In 2017, there are 83 new FDI in ASEAN states mainly in Indonesia, Malaysia Vietnam and Singapore. In general, the Guangdong's FDI investments to Singapore, Thailand, Malaysia and Indonesia were reduced while the ratio to the ASEAN States with higher investment risks such as Cambodia, Myanmar and Laos were gradually increased. [8] Guangdong's MNEs, established around three hundred foreign offices in ASEAN States and 57 oversea marketing offices and branches, which were mainly contributed by renown enterprises in the country such as Huawei, Midea, TCL, Guangdong Agribusiness Group, Guangdong Guangxin Holding Group, and Country Garden Holding. [9] Indications of the report from the Department of Commerce of Guangdong Province are that non-SOEs have heavily engaged in the FDI in Southeast Asia and expanded their businesses into multiple and high-end business construction projects ever since the launch of OBOR initiatives.

Despite the salient decline of China's total outward investment, three features that characterize China's outward investment remain. The principle distinctive features of China's oversea investment are state-owned enterprises (SOEs), which supplied $49.1 \%$ of China's total non-financial outward investment in 2017 and decreased 5.2\% compared to the share in 2016, whereas the non-state enterprises had reached $50.9 \%$. The other feature highlighted in the 2017 Statistical Bulletin of China's Outward Foreign Direct Investment report addresses the multiple subject matters of China's Foreign Direct Investment (FDI) in the OBOR and ASEAN States. The three major sectors of those FDI flowed to manufacturing, wholesale and retail trade, lease and business services. In addition, the most sensitive investment sectors, such as transportation production and supply of electricity, heat, gas and water have been decreased distinctively in the recent year. Lastly, apart from Greenland investment, mergers and acquisitions ( $M \&$ As) in the OBOR route that has become an essential outward investment mode reached 16.28billion USD in 2017 and soared $145 \%$ comparing to 2016 , accounting for $13.6 \%$ of China's total M $\&$ As. [10] Chinese multinational enterprises (MNEs) have also been characterized to apply the Build-Operate-Transfer (BOT) and Public-Private Partnership (PPP) modes of project contracting, thus expanding the round-tripping investments in Chinese Hong Kong and overseas.

\subsection{Building ASEAN-China Investment Agreements Framework}

While China's outward investment is flourishing in ASEAN, a network of Bilateral Investment Treaties (hereinafter as BITs) and regional investment agreements have substantially evolved over time, reflecting China's shift from an inward to an outward FDI country..In general, China is building a sophisticated regulatory framework, both facilitative and protective of Chinese outward FDI in ASEAN, which has moved from an approach of restricting investment to an investment protection approach within two decades. [11] Since 1985, China progressively signed the BITs with ten ASEAN nations, from the first 1985 ChinaThailand BIT, to the later 2001 China-Myanmar BIT. [12] Nevertheless, these BITs vary on the proposed standards of compensation and investor-state arbitration.

ASEAN countries and China have extensively liberalized trade in goods, services, and investments by signing a series of agreements that were launched by the Framework Agreement on Comprehensive Economic Cooperation on 4th of November 2002 which formed the legal basis for the creation of the ASEAN-China Free Trade Area (ACFTA). [13] Under the ACFTA, there are three agreements aiming for free flow of goods, services, and investments: ASEANChina Trade in Goods Agreement that provides tariff reduction and elimination for tariff lines categorised as either 'normal track' or 'sensitive track'; Agreement on Trade in Services that is to liberalize and eliminate discriminatory measures with respect to trade in services among the parties in various service sectors; Investment Agreement that is to promote and facilitate investment flows within the China and the ASEAN states. On $15^{\text {th }}$ of August 2009, ASEAN and China concluded the Agreement on Investment of the Framework Agreement on Comprehensive Economic Cooperation between the PRC and ASEAN (hereinafter referred to the Investment Agreement). This agreement constitutes one of essential trading arrangements under the Framework Agreement on Comprehensive Economic Cooperation of ACFTA, which took full effect on 1 January 2015. [14] This agreement provides free, transparent and justice investment mechanism for investors from both sides and ensures most-favored-nation treatment, nondiscriminatory treatment on nationalisation or expropriation, fair and equitable treatment on reciprocal investment and compensation for losses. The investment agreement raises the standard of investment protection via the establishment of a national treatment, the extension of an a priori consent to international arbitration, and a clarification of the standard of compensation. [15]

2012 Plan of Action to Implement the Joint Declaration on ASEAN-China Strategic Partnership for Peace and Prosperity (2016-2020) first highlighted commission for the Parties to assist enterprises to take advantage of the benefits arising from the ACFTA agreements by enhancing investment and 
undertaking cooperation in investment facilitation. [16] The "Protocol to Amend the Framework Agreement on Comprehensive Economic Co-operation and Certain Agreements thereunder between ASEAN and the People's Republic of China" (ACFTA Upgrade Protocol) which was signed on 21 November 2015 further strengthened and complemented the legal basis for outward investment of businesses from ASEAN and China. [17] Under the ACFTA Upgrade Protocol, ASEAN and China agreed to explore and undertake new commitments in terms of Goods, Services and Investment to bring the Parties closer in realizing their goals of investment of US $\$ 150$ billion by 2020. [18] Chapter 3 amendments the Investment Agreement with two suggestive clauses on promotion and facilitation of investment. To promote investment, the Parties shall actively encourage and create favourable conditions for investors and their investments, as well as increasing awareness of the Parties via organizing investment promotion activities, enhancing industrial complementation and production networks. The facilitation clause calls each Party to further create stable, favourable and transparent conditions in order to encourage greater investment, to cooperate through simplifying procedures for investment applications and approvals, and establishing one-stop investment centres or mechanisms to offer assistance and advisory services to the business sectors.

China's OBOR initiative and the "Going Out" strategy has energized Chinese MNEs investing in ASEAN and enhanced the growth of foreign offices for seeking industrial resources. [19] China's active and sudden promotion of regional cooperation in Southeast Asia has brought uncertainty and suspicion among its neighbors. This is inextricably related to the extent with which China can meet the hostilities of Southeast Asian States and adopt a diplomacy of benevolence and reciprocity. [20] Nevertheless, China's resurgence comes at a price such ashe suspension of the Myitsone dam on the Irrawaddy River in 2011, and the failure of an exchange project on high speed train which connects China and Thailand.

The studies on the ACFTA mainly focuses on examination of the scope, national treatment, dispute settlement of ASEAN-China Investment Agreement via doctrinal legal analyses on its provisions. Sauvant and Nolan (2015) observes the features of China's International Investment Agreements and trends of China's outward FDI in key host countries and points out the challenges of Chinese growing FDI. [21] Jun Xiao (2011) analyzes the provisions of Investment Agreement in comparison with the existing BITs between China and individual ASEAN member states and stresses the trend that although the Investment Agreement is a regionalization of China's BITs, China was not prepare to incorporate investment liberalization obligations in its FTAS. [22] As the increase of Chinese outward investment in ASEAN, many Chinese scholars, such as Wei Yanru (2011) [23], Lu Xuewu (2013) [24] and Zhang Qinlin (2014) [25] start to draw attention to the mechanism in balancing the interests of investment liberalization with host countries under the ACFTA by noting the insufficient function of
Investment Agreement.

Although ASEAN countries and China agreed on further liberalization in investment, the effects of ASEAN-China Investment Agreements and Chinese BITs with ASEAN member states in place have rarely been discussed and examined via empirical studies such as surveys, interviews and field studies. As China has gone into the transformation period from a capital-importing to a capital-exporting country, it is indispensable to observe the effects of Investment Agreements and BITs on risk prevention and safeguarding investment interests from the perspectives of Chinese multinational enterprises. To this end, in 2016 and 2017, this studies selects 30 state-owned enterprises and private companies among 300 Guangdong business in which largely invested in ASEAN to explores major investment risks, investment disputes settlement mechanisms, and legal barriers of China's multinational enterprises in ASEAN member states. This study also raises the issues of insufficient investment protection laws on China's outward investment, the obstacles in investment treatment and high political risks as a result of Chinese outward investment in ASEAN.After assessing the challenges and obstacles ahead from data analyses, surveys and field study,, it offers optimal suggestions for Chinese MNEs to minimize investment risks and to safeguard their interests in ASEAN states.

\section{Features and Implications of Guangdong's Outward FDI in ASEAN}

\subsection{Features of Outward FDI in ASEAN}

The investment protection provided by host ASEAN states is largely included in the scope and coverage of the "investment" item laid down by the Investment Agreement and China-ASEAN BITs. Both investment arrangements define the scope of investment using broad asset-based methods and itemize five categories of investment: movable and immovable property; shares, stocks, and debentures; claims to money or to any other performance with an economic value; intellectual property rights; and business concessions to cultivate, extract, or exploit natural resources conferred by law or under contract permitted by law. [26] However, the protection of investment does not extend to any tax measures, government procurement-related measures, or government related services, and limited by relevant laws, regulations, and policies of the host states. [27] To assess the effects of investment protection and investment liberalization status provided by these investment arrangements, a survey has been conducted on six Guangdong enterprises via data analyses and interviews regarding the key elements of the Investment Agreement, types of investment, investment risks, admissibility of the investment, most-favored-nation treatment (MFN), fair and equitable treatment (FET), investor-state dispute settlement resolution, expropriation and compensation, foreign investment insurance, and social and environmental responsibility of Chinese enterprises.

With regard to the scope of investments within ASEAN 
states, only qualified investments and investors enjoy protection under the investment framework. China revised its Administrative Measures for Overseas Investments in 2014, which define the terms "overseas investment" or "outbound investment" as "activities of possessing non-financial enterprises or acquiring the ownership of, the control over, the operation and management right of, and other rights of and interests in, existing non-financial enterprises outbound through consolidation, merger, and acquisition, or otherwise conducted by Chinese enterprises". [28] Enterprises that invested in ASEAN states confirmed that state-owned or state-controlled Chinese enterprises are keen to cooperate with enterprises of host states to form a new company in a joint venture; in contrast, private companies operate in the form of investment affiliate branches or subsidiary companies.

The interviews results obtained from Chinese SOEs show the progressive transformation of Chinese FDI in ASEAN states, which departed from the traditional two party joint venture investment and flourished in a joint venture with transnational investors or in the form of merger and acquisition. The Guangdong Guangken Rubber Group (GKR), which is the first Chinese rubber company that engaged in overseas rubber farming, seedling breeding, planting, research and development, as well as processing and trading, has been running several joint venture companies in Thailand, Indonesia, Malaysia, Cambodia, and Singapore. [29] The GKR cooperated with the Bornion Timber and invested $50 \%$ of its shares (USD 3.57 billion) to form a joint venture company in 2009 which is the Bornion Guangken Rubber Sdn Bhd (BGR).Also the GKR completed the acquisition of $60 \%$ stake of Thai Hua Rubbr Public Co, the world's third largest natural rubber group in 2016. Guangdong Guangxin Holding is a provincial state-owned trading enterprise that has invested in Vietnam, Indonesia, and Singapore through a multiple joint venture with local companies and multinational enterprises from Japan and Chinese Hong Kong. [30]

Two features characterize private Chinese MNEs in ASEAN. Firstly, private MNEs such as Huawei, a networking and telecommunications equipment and services company headquartered in Shenzhen Guangdong, is keen to form subsidiaries in ASEAN nations. In 2015, Huawei achieved significant growth with an annual revenue that reached CNY 395,009 million, which is a $37 \%$ increase compared to the previous year. [31] Huawei established two subsidiaries in Southeast Asian states, namely the International Pte. Ltd. in Singapore for the distribution of telecommunication products, and Huawei Tech Investment in Indonesia for the development and sale of telecommunication products as well as ancillary services. Midea, a Chinese electrical appliance manufacturer (listed on the Fortune 500 and headquartered in Foshan, Guangdong) opened its first overseas production facilities and vital strategic base in 2007 in Binh Duong Province of Vietnam. [32] As China's leading property company, Country Garden Holding Ltd. (based in Shunde Guangdong) entered a joint venture and incorporated the company Country Garden Pacific view Sdn. Bhd with the Malaysia government owned company Esplanade Danga 88 Sdn Bhd, for the joint development of residential and commercial properties on four reclaimed islands. [33]

\subsection{Treatment of Investment in the Host ASEAN States}

The ASEAN Investment Agreement signals China's acceptance of high-level investment protection for the general treatments of investment, which incorporates fair and equitable treatment, full protection, and security of investments (Article 7), as well as the accordance to investor and investments of national treatment (NT) status at the postestablishment stage and MFN treatment at both the preestablishment and post-establishment stages. Unlike the old versions of BITs that were generally devoid of NT clauses, [34] article 4 of the China-ASEAN Investment Agreement provides a ground-breaking national treatment status for investors and investments with respect to the "management, conduct, operation, maintenance, use, sale, liquidation, or other forms of disposal of investments". Similarly, among 11 China-led Free Trade Areas, the post-establishment model is commonly used in the NT clause, exemplified by Chapter IX of the China-Pakistan FTA, Article 92 of the China-Costa Rica FTA, China-New Zealand FTA, and the China-Peru FTA that grant the post-establishment NT as a core principle. [35] In addition, Article 6 of the Investment Agreement further restricts NT and MFN obligations to any existing or "new" non-conforming measures adopted by any party, as well as the continuation or amendment of these nonconforming measures, or namely the "grandfather clause", that exempts the party from investors' claims over pre-existing law. Xiao emphasized that without the preestablishment of national treatments, there is no obligation of investment liberalization and investment protection could be largely undermined by such restrictions. [36]

In general, the MNEs participating in the interview and survey indicate that NT, MFN, and FET have been well equipped to investors and investments in accord with the Investment Agreement. With regard to the national treatment, the housing project, Country Garden Pacific view Sdn. Bhd in Malaysia could enjoy permanent property rights for the real estate, an exemption of extra-approval formalities, and a one-stop service and investment approval procedure. Apart from the general investment benefits aforementioned, foreign investment or investors in ASEAN states are typically subject to local requirements of the employees, foreign ownership limits, and specific thresholds of total charter capital. Vietnam issued Investment Law in 2014 and an amendment thereof in 2015, outlining that a foreign invested economic organization (FIEO) shall satisfy a $51 \%$ threshold of the total charter capital, subject to the duration of investment projects and more stringent licensing requirements under the law, if an investment project is located within an economic zone. [37] In particular, holdings of foreign investors at stateowned companies that have been equitized or converted shall limit the volume of charter capital invested in business organizations in Vietnam. [38] Moreover, Indonesia's 
Investment Law specifies that unless otherwise stipulated by prevailing laws and regulations, foreign investment shall happen in the form of a limited liability company incorporated in Indonesia in bearing obligation to prioritize Indonesian manpower. [39] In other words, the "grandfathering provisions" continue to apply to foreign investments. Thus, it remains questionable to exclude these investment barriers imposed by ASEAN members on certain industries in which member states are unable to liberalize or accord national treatment to consider the protection and interests of domestic industries and SMEs.

In contrast, the reservation lists of ASEAN Comprehensive Investment Agreement on 26th of February 2009 (ACIA), which are submitted by each ASEAN member state to the ASEAN Secretariat for endorsement by ASEAN Investment Agreement Council, encompassed the measures that do not apply to national treatment. [40] To ensure the progressive elimination of such reservations, leaders from each member state agreed to adopt a negative list on the reservation in accordance with the three Phrases of the Strategic Schedule introduced by the AEC Blueprint. [41] Due to China' s increasing engagement into the outbound investment and the full implementation of negative lists in China's Pilot Free Trade Zones, [42] this flexible treatment of reservation lists is likely providing a reference for the future revision of the ASEAN-China investment agreement.

\subsection{Observations from the Interview and Survey}

The Guangdong enterprises that participated in the interviews prioritized eight investment risks. These are political risks, market fluctuation risks, foreign exchange risks, legal risks, bureaucratic corruption, social risks, environmental risks, and the risk of cultural integration. The top three risks are foreign exchange risks, market fluctuation risks, and political risks. With regard to foreign exchange risks, it appears that enterprises such as Huawei have managed functionally, via a complete set of foreign exchange management policies, to minimize the risks arising from buying, selling, and financing with currencies of the CNY. [43] The Guangken Group indicates that the risks arising from market fluctuation have been substantially higher since the price of rubber dropped from five-thousand per ton in 2008 to ten-thousand per ton in 2013. [44] Political risks are frequently mentioned in interviews and specified in the strike against overseas Chinese in 2014 in Vietnam. [45] All enterprises express that it is highly unlikely that they would restore international arbitration or domestic courts in host states in the event of political risks or investment disputes. Two reasons contribute to the reluctance for dispute settlement mechanisms. First, the political risks of the SOEs are fully covered by the insurance provided by the China Export \& Credit Insurance Corporation (Sinosure). [46] A private company in contrast, has to hedge the abovementioned risks by using business risk management techniques. Second, the default phases of first generation BITs restricting the subject matter in the investor-state arbitration might block many from seeking investment arbitration. To this regard, Shen suggests that China should start to revise relevant first-generation BITs and seek a balance between investment protection and interests of host states in consideration of its shift from an investment import country to an investment export country, and integrate modern treaty protections.[47]

\section{Improving the Investor-State Dispute Settlement Regime}

\subsection{Access to Investor-State Dispute Settlement (ISDS) Under the ACIA}

The Investment Agreement shows the following characteristics concerning disputes between an investor and a State. First, disputes concerning an alleged breach of obligations under Article 4 (National Treatment), Article 5 (Most Favored-Nation Treatment), Article 7 (Treatment of Investment), Article 8 (expropriation), and Article 9 (compensation for losses) shall be settled in three ways: by consultations, domestic court, and arbitration. [48] However, these disputes shall only limit the investment with respect to the management, conduct, operation, sale, or other disposition of an investment, namely the post-establishment investment. [49] Article 13, paragraph 3 emphasizes the importance of consultation proceedings in which both parties must first resolve their dispute via written request for consultations within a limited period of time. Unlike the general dispute settlement mechanism of the ACFTA, which offers a 30-day time limit for further proceeding to arbitration, [50] the investment agreement offers six months for consultations. In cases where the disputes cannot be solved, the investors (at any time upon which they reach agreement) can submit a claim to the national court of the host State and recourse to four international arbitration procedures under the International Centre for Settlement of Investment Disputes Convention (ICSID) or arbitration under the UN Commission on International Trade Law. [51]

Second, a "fork-in-the-road" clause, that prohibits a complaint to reach a dispute before the international arbitration if the dispute has been submitted to a domestic court, is softened in terms of methods and numbers of States that apply this clause. Article 14 paragraph 5 mandates the choice of procedures for investors between an international dispute settlement and the respective domestic court. In Indonesia, the Philippines, Thailand, and Vietnam, as soon as an investor has submitted the dispute to competent courts or administrative tribunals, the choice of procedure is final. This rule is softened in that the investor can first file a claim in the respective domestic court and later submit the case to achieve an international dispute settlement, provided that the investor has withdrawn the case from the domestic court and meets conditions under Article 14 (6). [52]

Third, the investment agreement specifies the extent and the conditions of diplomatic efforts and whether these are prohibited or allowed in parallel to ISDS proceedings. Unless a State party fails to execute an award obtained against it, no 
State shall provide diplomatic protection in investor-State investment disputes once one of the investors and the host States have consented to either conciliation or arbitration under Article 14. [53] Nonetheless, informal diplomatic exchange to facilitate the settlement of the dispute are still allowed. Furthermore, the clauses do not clarify the meaning of informal diplomatic exchange and its distinction from consultations. Inclusion of clauses regulating diplomatic support is rarely found in investment treaties; [54] however, this might characterize the essential needs of ASEAN States and China for supplementing main stream investment fora via informal diplomatic methods, that might be inherited from the "ASEAN Way".

\subsection{Access to International Arbitration Under China-ASEAN BITS}

China-ASEAN BITs, which are dominated by firstgeneration BITs provisions, [55] often contain language limiting access to ISDS with respect to scope; typically, these are directed at the amount of compensation. [56] These sections on ISDS contain language mentioning the scope of possible claims, the description of which could be broad such as "any legal dispute in connection with an investment" (China-Myanmar BIT), "disputes concerning investment" (China-Brunei BIT), "disputes whole parties have agreed to refer to arbitration" [57], or in a restrictive language "disputes involving the amount of compensation" [58] Since the gradual broadening of China's consent to international arbitration for ISDS, ICSID, as well as ad hoc tribunals are by far the most often mentioned as potential fora, other fora should also be touched upon, including the International Court of Justice [59] the International Chamber of Commerce (ICC), [60] and the regional tribunals in Stockholm. [61] As mentioned above, the ISDS disputes that China agreed to arbitrate under a BITs with ASEAN States largely depend upon the generation of BIT since the first-generation BITs only allow default disputes that "involve" the amount of compensation for expropriation.

Compared to the volume of investment treaties China concluded since the early 1980 s, the cases that have been brought pursuant to a Chinese BIT are insignificant and surprisingly scarce. The reasons are likely complex and pragmatic. Given the restrictions on the scope of international arbitration, foreign investors (including Chinese investors aboard) may be discouraged from wasting time and money on an ISDS case. The reason derives from the fact that China has expressly excluded the enforceability of investor-state awards when signing the 1958 New York Convention on the Recognition and Enforcement of Arbitral Awards. Also, China adopts a rigid position on sovereignty and strictly adheres to the principle of absolute sovereign immunity. [62].

The recent arbitration of Sanum Investments Ltd. V Government of the Lao People's Democratic Republic ("Sanum v Laos"), reflects a method of interpretation of the default dispute resolution article of China's first generation BITs and China's position on the applicability of PRC BITs to the Chinese Special Administrative Regions, and it sends a warning signal to Chinese MNEs in ASEAN states. Sanum is a Macau-based company that invested in the gaming and hospitality industry in Laos through a joint venture, commenced arbitral proceedings under the PRC-Laos BIT against Laos on $14^{\text {th }}$ of August 2012, and alleged that Laos deprived them of the benefits from their capital investment via imposition of unfair and discriminatory taxes. [63] An arbitral tribunal was awarded On 13th of December 2013, and was later challenged by Laos before the High Court in Singapore on the grounds that Sanum does not qualify as an "investor" under Article 1 (2) (b) of the PRC-Laos BIT since the territorial scope of the PRC-Laos BIT does not include Macau under the "one country, two systems" policy; furthermore, Sanum's claims on the propriety of state taxation measures exceeded the scope of Article 8 (3) of the PRC-Laos BIT, which only applies to disputes involving the quantum of compensation for expropriation; therefore, the claims were not arbitrable. The High Court granted the Laos' application, annulled the award, and held that the BIT concerned did not extend to Macau on the basis of two diplomatic notes from the Lao Ministry of Foreign Affairs and the PRC Embassy in Vientiane, respectively, a 1987 PRC-Portugal Joint Declaration on the question of Macau, and the experience of the PRC and the United Kingdom with respect to Hong Kong. After examining the limited scope and intention of all Parties that submitted a dispute to arbitration by the time signing the BIT and the restrictive features of PRC's "first generation" BITs, the High Court further held that the phrase of "a dispute involving the amount of compensation" in Article 8 (3) should convey a restrictive rather than expansive interpretation. [64].

On 29th of September 2016, the Singapore Court of Appeal (SGCA) reversed the High Court's decision on both grounds and held that given the primary object and purpose of the BIT (namely the promotion of investment and the protection of investors), the context surrounding Article 8 (3) was consistent with a broad interpretation of Article 8 (3). [65] Although the issue of whether or not diplomatic notes should be admitted as evidence and have legal effects on the result of application remains ambiguous and is a fertile area for research. China strongly opposed the ruling made by the SGCA and emphasized that the application of investment treaties to Macao SARs should be in line with the "one country, two systems" policy as well as the Basic Laws of Macau. [66] To this end, after seeking the opinions of the governments of Macau SARs, the Chinese central government can decide whether to apply the international treaties signed by the PRC to the Macau and Hong Kong SARs, which can conclude agreements with foreign countries in the appropriate fields of economy, finance, trade, and investment, in accordance with basic laws. [67] Therefore, China's position on the applicability of PRC BITs to the SARs remains clear, namely that the investment agreements between the PRC and foreign countries do not apply to the SARs unless otherwise decided by the central government after seeking the standpoint of the government of the SARs 
and consulting with the contracting parties of the agreement.

For Chinese MNEs, which based their business in Chinese Hong Kong and Chinese Macau as springboard to their investment overseas, these investments might be exposed to much higher risks of expropriation and nationalization from host states than Chinese MNEs based on mainland China. Among the enterprises participating in the interview, one expressed concerns regarding the application of PRC's BIT to Hong Kong as they had expanded their business by using their Hong Kong office for tax and financing planning purposes. Until February 2016, 17 BITs were signed between Hong Kong SAR and foreign countries and two BITs were signed between Macao SAR and foreign countries, [68] among which only Thailand has signed BIT with Hong Kong SAR in 2006. In contrast, China signed 145 BITs with most countries around the world. [69] In practice, the new generation PRC's BITs excluded the PRC's BITs from application to the SARs, such as Article 3 (1) (b) of the ACIA referring to the "investors" of the party within its territory that is the customs territory of China according to the WTO definition at the time of China's accession to the WTO.

\section{Suggestions for the Promotion and Facilitation of Chinese Outward Investment in ASEAN States}

\subsection{Prevention of Political Risks via Seeking Insurance from $M I G A$}

The report released by the World Bank in 2016, measuring the regulations that affect 11 areas of the life of a business, indicates that the status of investment protection in ASEAN states is satisfactory. Among 189 States, Singapore ranked No. 1, followed by Malaysia (18), Thailand (49), Brunei (84), Vietnam (90), the Philippines (103), Indonesia (109), Cambodia (127), Laos (134), and Burma (167). [70] To prevent political risks in ASEAN, the investors might need to closely monitor political movements and frequently channel business information either from Chinese embassies or host states.

To control business risks and political risks costefficiently, the Chinese investor could rely on the Multilateral Investment Guarantee Agency (MIGA), which has barely been integrated in the risk management scheme despite the fact that China signed the MIGA Convention in 1988. MIGA guarantees the protection of investment against political risks and can also help investors to obtain funding at preferential financial terms and conditions. [71] Most importantly, the coverage of political risk insurance is broader than the coverage of Sinosure, particularly regarding matters of Currency Transfer, War and Civil Disturbance, or specific non-commercial risks approved by the Board. [72] Furthermore, such an insurance provided by MIGA invites many market players and contributors of MIGA including the host states, which could largely ease the political risks and formulate Chinese MNEs' investment activities in ASEAN states.

\subsection{Minimizing Investment Risks by Advancing Investment Treaties}

Investment protection has mainly been achieved through investment treaties either in the form of BITs or as an investment agreement. Most BITs between PRC and ASEAN are more than 20 years old and are categorized as the first generation BIT, containing narrow scope of arbitrable investment and ambiguous phases such as "the disputes involving the amount of compensation for expropriation". The Sanum and Laos case is alarming for the law maker as well as these Chinese MNEs invested in ASEAN States. Despite the fact that China's outward flow of investment has increased in the wave of the OBOR, few disputes arose under China's BITs. The preference for mediation or other informal means of dispute resolution might explain the scarcity of investment arbitration cases. [73] Additionally, the issue of PRC's BITs application to its SARs has surfaced and subsequent mutual recognition by the central government or further measures needs to be conducted under the premise of the SARs basic law. China, which entered the age of outbound investment and takes a lead in capital-export, has advanced and evolved investment treaties by adopting recent investment protection standards, accepting ICSID arbitration of disputes against investors, agreeing to the preestablishment National Treatment on the basis of a negative list, and heavily engaging in a 5th generation international investment agreement. [74].

Regardless of whether the SOE is a qualified "investor" under the investment treaty has aroused significant attention. [75] The ICSID case clarified the test as to whether the SOE in question is qualified as an investor and can receive correspondent investment protection; a SOE is performing State functions when it takes advantage of such State policies and proceeds to restructure itself to obtain a strong position to compete in a free market economy; a SOE takes measures to achieve the objectives involving the performance of State or governmental functions. [76] To this end, China and ASEAN have incorporated the definition of a "juridical person of party" in Article 1 (1) (f) of the investment agreement, which indiscriminately includes any legal entity duly constituted or organized under the law of a party regardless of whether it is a privately-owned or governmental-owned entity in substantive business operations. Thus, it is indispensable to apply this test on the SOEs that have achieved competitive advantages over the private counterparts in the FDI or embrace the relevant concept of "competitive neutrality", which aims to impose disciplines on the measures supporting outward FDI by SOEs.

\subsection{Completing the OBOR with a "Going-In" Strategy}

Implications from the interviews and surveys suggest that the success of outward FDI in ASEAN can be achieved by realizing the localization and engaging in various corporate 
social responsibilities. The Huawei Indonesia company was formed in 2000, and is now one of the biggest foreign enterprises in Indonesia with $80 \%$ of Indonesian employees. Similarly, Guangken Groups indicates that $95 \%$ of employees are locals. [77] Huawei leads the sustainable investment by aligning the business strategy to reflect its commitment to promoting a harmonious and healthy development of the economy, the environment, and society. [78] Huawei adopts the concept of sustainability in its products and manufacturing process. In addition, Huawei initiated charity projects with the local government, customers, and non-profit organizations, which include supporting information and communication technology (ICT) innovation, facilitating green initiatives of local communities, and cultural, sports, and traditional events, enabling ICT talent education and the support of underprivileged groups. In the Philippines, Huawei supports start-ups that participate in technology competitions. In Myanmar, Huawei donated equipment to a local university. In Vietnam, Huawei funded the ICT knowledge competitions and provided scholarships for local schools to facilitate ICT knowledge transfer.

Chinese MNEs have sensed the instruments and strategy of "going-in" for constructing the OBOR when the investments are sensitive for either national security or natural resources. Whether the investors are privately-owned enterprises or SOEs, they endeavor to become a good corporate citizen through sourcing from local suppliers, employing nationals for its daily management, and contributing their business profits to the local community in host countries. Professor Yao Meizhen, an eminent Chinese scholar in investment law, emphasized that the relations to international investments are barely a generous "gift", but the mutual interdependent benefits between investor, host state, and capital-exporting state. [79] With investment laws ahead, China should pay more attention to enforce various instruments and regulatory frameworks to support and ensure the outward investments abroad are in line with the interests of host states and a sustainable FDI.

\section{Conclusion}

The launch of "Belt and Road" Initiative have offered enormous opportunity to the investment between ASEANChina as well as aroused unstoppable flourishing of Chinese outward FDI in ASEAN. Connectivity projects as the ChinaThailand high-speed railway, Indonesia's Jakarta-Bandung high-speed railway, China-Laos Railway are under construction. China and ASEAN are working closely and finalizing negotiations for a modern, comprehensive and mutually-beneficial Regional Comprehensive Economic Partnership (RCEP) to further facilitate investment in the region. Meanwhile, the results from the studies suggests that political risks, trade barriers, investment impediments were still entrenched in some ASEAN member states in the courses of Chinese MNEs' investments. Essentially, by engaging multiple political insurances, advancing ASEAN-China Investment Agreements, and adopting the strategic business plan, the interests of China's outward investment in ASEAN could be protected. In the long run, the critical way to avoid investment risks depends on the constructive balance between the Chinese outward investment with the host ASEAN member states that instituted by the investment agreements and wider mutual beneficial cooperation under the framework of building a shared ASEAN-China community.

\section{Acknowledgements}

This research is funded by 2015 Research Project of Guangdong Social Science, entitled the research on the mechanism in balancing investment protection of Guangdong enterprises with the interests of ASEAN states under the framework of One Belt One Road, project code (GD15XFX02) and Guangdong University Distinctive and Innovative Project, entitled China's investment protection mechanism to ASEAN under the Belt and Road Initiatives, project code (2017WTSCX038). The authors would like to express great gratitude to all the Guangdong corporation taken interviews and questionnaire

\section{References}

[1] National Development and Reform Commission, Ministry of Foreign Affairs, and Ministry of Commerce of the People's Republic of China (2015) Vision and Actions on Jointly Building Silk Road Economic Belt and the 21st Century Maritime Silk Road, available at http://en.ndrc.gov.cn/newsrelease/201503/t20150330_669367. html.

[2] Jiping GUO (2018) "The Belt and the Road is the Great Way in Building the Shared Destiny For Mankind" (Translation added) Renming Daily, 06 October, 2018, http://cpc.people.com.cn/n1/2018/1004/c6409430325277.html 018, last visited on 14 February 2019.

[3] China's outward investment flows in 2017 that downed 19.3\% comparing to the figures of 2016 , accounts for $11.1 \%$ of world outward investment flows. See Ministry of Commerce People's Republic of China (MOFCOM), 2018 Report on Development of China's Outward Investment, (December 2018), available at http://images.mofcom.gov.cn/fec/201901/2019012815534815 8.pdf, last visited on 14 February 2019.

[4] Ministry of Commerce of the People's Republic of China, National Bureau of Statistics, State Administration of Foreign Exchange, 2017 Statistical Bulletin of China's Outward Foreign Direct Investment, available at http://www.fdi.gov.cn/1800000121_33_11652_0_7.html. last visited on 13 February 2019 . In terms of countries destination of investment flows, Singapore ranked first with $\$ 6.32$ billion, accounting for $44.8 \%$ of the total investment flow to ASEAN, mainly to wholesale and retail trade, leasing and business services; Malaysia ranked second with $\$ 1.722$ billion, accounting for $12.2 \%$, mainly to manufacturing, real estate, and construction; Indonesia ranked third and reached $\$ 1.682$ billion, accounting for $11.9 \%$, mainly to manufacturing, construction, electricity, heat, gas and water production and supply. 
[5] The manufacturing sector received $\$ 3.17$ billion, with a yearon-year decrease of $10.4 \%$, accounting for $22.5 \%$ and the flows were mainly concentrated in Indonesia, Thailand, Malaysia, Vietnam, etc. And the production and supply of electricity, heat, gas and water sector received $\$ 0.63$ billion, accounting for $4.5 \%$ of the total and the flows were mainly distributed in Indonesia, Myanmar, Laos, etc. ibid.

[6] See page 139 of Ministry of Commerce People's Republic of China 2018 Report on Development of China's Outward Investment.

[7] Yanhua MAO etal., the Blue Paper on the Guangdong's Participation in the Belt and Road Initiative (2013-2018) (translation added), Guangzhou: Guangdong People's Press, 2018, p132.

[8] Yanhua MAO etal., the Blue Paper on the Guangdong's Participation in the Belt and Road Initiative (2013-2018) (translation added), Guangzhou: Guangdong People's Press, 2018, pp 142-143.

[9] Report on the development and status of "going-out" of Guangdong's enterprises (translation added), issued by Department of Commerce of Guangdong Province in 2016.

[10] Page 95 of Ministry of Commerce People's Republic of China 2018 Report on Development of China's Outward Investment.

[11] Karl P. Sauvant and Victor Z. Chen (2013) China's Regulatory Framework for outward Foreign Direct Investment, China Economy Journal 7, pp141-163, 141.

[12] Except for China-Brunei BIT that signed on 17 November, 2000., nine BIT remain enforceable, which are ChinaSingapore BIT (21 Nov. 1985), China-Malaysia (11 Dec. 1988), China-Philippines BIT (20 July 1992), China-Vietnam BITs (2 Dec. 1992), China-Laos BIT (31 Jan. 1993), ChinaIndonesia BIT (18 Nov. 1994), China-Cambodia BIT (19 July 1996), China-Myanmar BIT (12 Dec. 2001). See available at http://investmentpolicyhub.unctad.org/IIA/CountryBits/42, last visited on 14 February 2019.

[13] See Key documents guiding the dialogue relations from ASEAN official website, https://asean.org/asean/externalrelations/china/\#968e439ab92bd0c4a.

[14] See Agreement on Investment of the Framework Agreement on Comprehensive Economic Cooperation between the PRC and ASEAN, http://fta.miti.gov.my/mitifta/resources/auto\%20download\%2 0images/558b8bd29bd01.pdf, last visited on 14 February 2019.

[15] Jun Xiao, (2011) The ASEAN-China Investment Agreement A regionalization of China's BITs, 6 Front. Law China 6 pp 241-258, at 254.

[16] Plan of Action to Implement the Joint Declaration on ASEAN-China Strategic Partnership for Peace and Prosperity, available at http://wtocenter.vn/chuyen-de/13080-china-aseanenter-new-era-of-deeper-strategic-partnership, last visited on 16 February 2019.

[17] Chapter 3 of Protocol to Amend the Framework Agreement on Comprehensive Economic Co-operation and Certain Agreements thereunder between ASEAN and the People's Republic of China", available at https://asean.org/storage/2012/10/Protocol-to-Amendthe-Framework-Agreement-ACFTA-Complete.pdf, last visited on 16 February 2019.

[18] ASEAN Secretariat Information Paper August 2018, available at https://asean.org/wp-content/uploads/2012/05/Overview-ofASEAN-China-Relations-August-2018_For-Website.pdf, last visited on 16 February 2019.

[19] See WANG Yongzhong and LI Xichen, "Features and Risks of China's Investment in the OBOR Counties" (translation added) HAN Bin and Wang Yongzhong (eds.), China Outward Investment Report third quarter of 2015, Beijing: China Social Science Press, 2016, pp 41-42.

[20] KE Jingjia (2015) The ASEAN-China Free Trade Area: Neighbors, Relatives or Foes? 1 China and WTO Review 2, pp 191-222, 209.

[21] Karl P. Sauvant and Michael D. Nolan (2015) China's Outward FDI and International Investment Law, Journal of International Economic Law, 18, Nov. pp 893-934.

[22] Jun Xiao, (2011) The ASEAN-China Investment Agreement A regionalization of China's BITs, 6 Front. Law China 6 pp $241-258$, at 254.

[23] Yanru Wei (2011) Comparative Studies on International Investment Law unde the ACFTA-on the background of signature and enactment of China-ASEAN Investment Agreement, China-ASEAN Investment Agreement" (translation added), Journal of Guangxi University, 1 pp 73-77.

[24] Xuewu Lu (2013) Analyses on Investment Rules under the ACFTA (translation added), Guangxi Social Science, 11, pp37-42.

[25] Qinlin Zhang, New Development of International Investment Agreements in perspectives of Public Interests, (translation added), Beijing: China Social Science Press, 2014, pp108-110.

[26] For details, see Article 1 of Agreement on Investment of the Framework Agreement on Comprehensive Economic Cooperation between ASEAN and China, available at http://fta.mofcom.gov.cn/inforimages/200908/2009081711300 7764.pdf, and Article 1.1 of BITs (P.R.C.-Brunei, Cambodia, Laos, Indonesia, Philippine, Myanmar, Singapore, and Vietnam) and Article 1.3 of China-Thailand BIT. Business concessions include contractual rights such as those under turnkey, construction or management contracts, production or revenue sharing contracts, concessions, or other similar contracts and can include investment funds for projects. See footnote 2 of the ASEAN-China Investment Agreement.

[27] Article 3 (4) of Agreement on Investment and footnote to Article 1.

[28] 2014 Administrative Measures for Overseas Investments, http://www.mofcom.gov.cn/article/b/c/201409/201409007233 61.shtml.The proportion of shares in control or management of Chinese MNEs is 10 percent. For detail, see Article 2 of 2006 Statistical System of Foreign Direct Investment, hzs.mofcom.gov.cn/accessory/201102/1297930121981.pdf.

[29] LI Wenfang (2016) Gcken to list Thai rubber producer, China Daily, 28 November 2016, available at http://www.chinadaily.com.cn/business/2016-

11/28/content 27500097.htm. Also see CHEN Min (2013) Seizing opportunity and harvest the overseas investmentstatus and experiences of Guangken under the "Going Out" policy, (translation added), 29 China Rubber, pp 18-20, 18.

[30] For detail please see company's official website http://www.gdftc.com/en/about/about.asp?t=1 and 2016 short term financing report of Guangdong Guangxin Holding (translation added), available at https://shclearing.com/xxpl/fxpl/scp/201607/t20160728_1708 97.html. 
[31] Huawei Annual Report 2015, http://wwwfile.huawei.com/ /media/CORPORATE/PDF/annualreport/AnnualReport2015_en.pdf?la=en.

[32] The subsidiaries in Vietnam include Midea Consumer Electric (Vietnam) Co.LTD and Midea Air-Conditioning Equipment (Vietnam) Co.

LTD, http://www.midea.com/global/about_midea/major_facilities/O verseas_Facilties/201403/t20140319_74645.shtml and, the Annual Report of Midea Group 2015, available at disclosure.szse.cn/finalpage/2016-03-26/1202084987.PDF.

[33] See introduction of the project from Country Garden Pacific View's profile, available at https://cgpvforestcity.wordpress.com/about/.

[34] Except for China-Myanmar BIT signing on December 12 2001, the rest of BITs between China and ASEAN members does not cover NT clauses. For more details, please see http://investmentpolicyhub.unctad.org/IIA/treaty/3272.

[35] China-Switzerland FTA and China-Singapore FTA, does not contain investment rules. See China Ministry of Commerce website, available

http://fta.mofcom.gov.cn/topic/enpakistan.shtml (last visited on Dec. 2, 2018).

[36] Jun Xiao, (2011) The ASEAN-China Investment Agreement A regionalization of China's BITs, 6 Front. Law China 6 pp $241-258$, at 249.

[37] Article 23 and 43 of Vietnam Law on Investment, 2014, Law No. 67/2014/QH13, November 26, 2014, available at http://www.xaydung.gov.vn/web/guest/legal-documents//legal/TB4r/en_US/18/250755/55213, last visited on 15 February 2017.

[38] Article 22 (3) (b) of the Vietnam Law on Investment 2014.

[39] Article 5 and 10 of the Law No. 25/2007 on Investment (Investment Law), available at http://www.flevin.com/id/lgso/translations/JICA\%20Mirror/en glish/3002_UU_25_2007_e.html, last visited on 26 February 2017.

[40] Article 8 of the ASEAN Comprehensive Investment Agreement.

[41] Article 46 of the ASEAN Comprehensive Investment Agreement.

[42] Notice of the General Office of the State Council on Issuing the Special Management Measures (Negative List) for Foreign Investment Access in Pilot Free Trade Zones, see http://www.lawinfochina.com/display.aspx?id=18995\&lib=la w, last visited 28 February 2017.

[43] See Huawei Annual Report 2015.

[44] CHEN Min (2013) Seizing opportunity and harvest the overseas investment-status and experiences of Guangken under the "Going Out" policy, (translation added), 29 China Rubber, pp 18-20, p 20.

[45] ZHANG Lujin and XIE Wei (2014) 'China's investors' choice of leaving Vietnam-haunting 72 hours' (translation added), China Economic Weekly, 26 May 2014.

[46] See

http://www.sinosure.com.cn/sinosure/english/English.html, last visited on 24 February 2017.
[47] SHEN Wei (2015) Liberalization and Pluralization of China's protection standards in international investment treaties' (translation added), Chinese Journal of Law 4, pp 184-208, 206.

[48] Article 13 (1) of the ASEAN-China Investment Agreement.

[49] Article 14 of the ASEAN-China Investment Agreement.

[50] Article 4 (3) of the Dispute Settlement Mechanism Agreement under the ACFTA.

[51] Section 4 of the Article 14 of the Investment Agreement.

[52] See note 5, pp 241-58 The conditions for submitting to arbitration are that the submission of the disputes must be within three years of the time at which the investor becomes aware of a breach of an obligation under the Investment Agreement; a ninety day advance written notice to the host state shall be given by the disputing investor before submitting the claim to conciliation or arbitration.

[53] Article 14 (8) of ASEAN-CHINA Investment Agreement.

[54] OECD papers shown $21 \%$ of the treaties in the sample contain clauses restricting explicitly diplomatic efforts. See Pohl, J., K Mashigo and A. Nohen (2012) Dispute Settlement Provisions in International Investment Agreements: A Large Sample Survey', OECD Working Papers on International Investment, 02, OECD Publishing. http://dx.doi.org/10.1787/5k8xb71nf628-en, last visited on 10 March 2018.

[55] Except for China-Brunei BIT and China-Myanmar BIT, which are both signed after 2000, the rest of BITs between China and ASEAN States are signed in the period of 1980s to 1990s.

[56] For discussion on generation of China's BITs, please see note 21, p 925.

[57] Article 10.2 of China-Philippine BIT and Article 7.4 of China -Malaysia BIT. China-Indonesia BIT.

[58] BITs in this sections are Article 13.3 of China-Singapore BIT, Article 8.3 of China-Laos BIT, Article 9.3 of China-Indonesia BIT, Article 8.3 of China-Vietnam, in comparison with 1985 China-Thailand BIT, the parties of which did not grant the access to the ISD

[59] Article 10.3 of Bilateral Investment Treaty between China and Philippine).

[60] Article 9.3 of Bilateral Investment Treaty between Chinaand Brunei).

[61] Article 13.5 of BIT (China-Singapore) and Article 7.4 of BIT (China-Malaysia).

[62] See note 21 at 932.Also see SHAN Wenhua and et al. International Protection of China's Outward Energy Investment- Survey and Regional Research (translation added), Beijing: Tsinghua University Press 2014, page 46.

[63] Paragraph 10 of Government of the Lao People's Democratic Republic v. Sanum Investments Ltd. [2015] SGHC 15, available at http://www.singaporelaw.sg/sglaw/laws-ofsingapore/case-law/free-law/high-court-judgments/15860government-of-the-lao-people-rsquo-s-democratic-republic-vsanum-investments-ltd-2015-sghc-15.

[64] Paragraph 121-126 of Sanum v. Laos, [2015] SGHC 15. 
[65] Sanum Investments Ltd v. Government of the Lao People's Democratic Republic [2016] SGCA 57 available at http://www.supremecourt.gov.sg/docs/default-source/moduledocument/judgement/judgment-for-ca-139-167-of-2015(final)-pdf.

[66] Foreign Ministry Spokesperson Hua Chunying's Regular Press Conference on October 21, 2016, available at http://www.fmprc.gov.cn/mfa eng/xwfw 665399/s2510 6654 01/2511_665403/t1407743.shtml, last visited on 16 March 2017.

[67] See Article 138 of the Macau Basic Law.

[68] Available at http://www.doj.gov.hk/eng/laws/table2ti.html, and João Santos Filipe, 'Bilateral Investment Treaties Quandary', 28 Politics, (January, 2015) see http://macaubusinessdaily.com/Politics/Bilateral-InvestmentTreaties-Quandary.

[69] See http://investmentpolicyhub.unctad.org/IIA/CountryBits/42, last visited on 16 February 2017.

[70] Ten of these areas are included in this year's ranking on the ease of doing business: starting a business, dealing with construction permits, getting electricity, registering property, getting credit, protecting minority investors, paying taxes, trading across borders, enforcing contracts and resolving insolvency. See World Bank Group, 'Doing Business 2016Measuring Regulatory Quality and Efficiency', A World Bank Group Flagship Report, 2016, 13th edition. p 5, available at espanol.doingbusiness.org/ /media/.../DoingBusiness/...Repor ts/.../DB16-Full-Report.pdf, last visited on 5 February 2017

[71] Available at https://www.miga.org/who-we-are, last visited on 8 March 2017.

[72] Article 11 of the Convention Establishing the Multilateral Investment Guarantee Agency.
[73] Wang Guiguo, 'Investor-State Dispute Settlement in China', Transnational Dispute Management, 5 (2011) page 7.

[74] Karl P. Sauvant and Michael D. Nolan (2015) China's Outward FDI and International Investment Law, Journal of International Economic Law, 18, Nov. pp 893-934.

[75] Karl P. Sauvant and Michael D. Nolan (2015) China's Outward FDI and International Investment Law, Journal of International Economic Law, 18, Nov. pp 893-934.

[76] Karl P. Sauvant and Michael D. Nolan (2015) China's Outward FDI and International Investment Law, Journal of International Economic Law, 18, Nov. pp 893-934, page 933.

[77] Claudia Annacker (2011) Protection and Admission of Sovereign Investment under Investment Treaties, Chinese Journal of International Law Vol. 10. No. 3, 531-564, 531.

[78] CSOB v Slovak Republic, ICSID Case No. ARB/97/4, Decision on Jurisdiction, 24 May 1999, paras 23-27.

[79] 2014 Administrative Measures for Overseas Investments, http://www.mofcom.gov.cn/article/b/c/201409/201409007233 61.shtml. The proportion of shares in control or management of Chinese MNEs is 10 percent. For detail, see Article 2 of 2006 Statistical System of Foreign Direct Investment, (translation added) hzs.mofcom.gov.cn/accessory/201102/1297930121981.pdf., at page 19.

[80] Huawei Annual Report 2015, https://www.huawei.com/en/press-events/annual-report/2015, at page 121, last visited on 8 March 2018.

[81] YAO Meizhen, Section of articles of YAO Meizhen, (translation added), Wuhan: Wuhan University Press, 2010, Page 33 and page 62. 